\title{
CORRESPONDENCE
}

\section{Giant cell tumor of tendon sheath-Use of fine-needle aspiration cytology for diagnosis}

\author{
Neha Meena ${ }^{1^{*}}$, Pooja Arora ${ }^{2}$ \\ ${ }^{1}$ Central Hospital, North Western Railway, Jaipur (Rajasthan), India \\ ${ }^{2}$ Department of Dermatology, Post Graduate Institute of Medical Education and Research, Dr. Ram Manohar Lohia Hospital, New Delhi, India
}

Citation: Meena N and Arora P. Giant cell tumor of tendon sheath-Use of fine-needle aspiration cytology for diagnosis. J Surg Dermatol 2022; 7(1): 138; http://dx.doi.org/10.18282/jsd.v7.i1.138.

*Correspondence to: Neha Meena, Central Hospital, North Western Railway, Jaipur (Rajasthan) - 302006, India; nehadermatologist@gmail.com

Received: $13^{\text {th }}$ July 2021; Published Online: $9^{\text {th }}$ August 2021

\section{Dear Editor,}

Giant cell tumour of the tendon sheath (GCTTS) is a slowgrowing, usually painless benign lesion of soft tissues ${ }^{[1]}$. We report the case of a 38-year-old male with a painless, slowly enlarging swelling on right thumb in order to highlight the role of fine-needle aspiration cytology (FNAC) in diagnosing GCTTS.

A 38-year-old male presented with a painless, slowly enlarging swelling on his right thumb from last six months. There was no history of injury to the affected area. On examination, there was a $3-\mathrm{cm} \times 1-\mathrm{cm}$ mass with normal overlying skin on the ulnar aspect of the right thumb at interphalangeal joint (Figure 1). It was non-tender, firm, well-circumscribed and fixed to the underlying structures with non-adherent overlying skin. X-ray of the right hand showed soft tissue swelling in the right thumb. Ultrasonography revealed a lobulated, well-defined, hypoechoic lesion in close approximation of the underlying tendon. However, the integrity of the underlying tendon was maintained. FNAC was suggestive of giant cell tumor of tendon sheath.

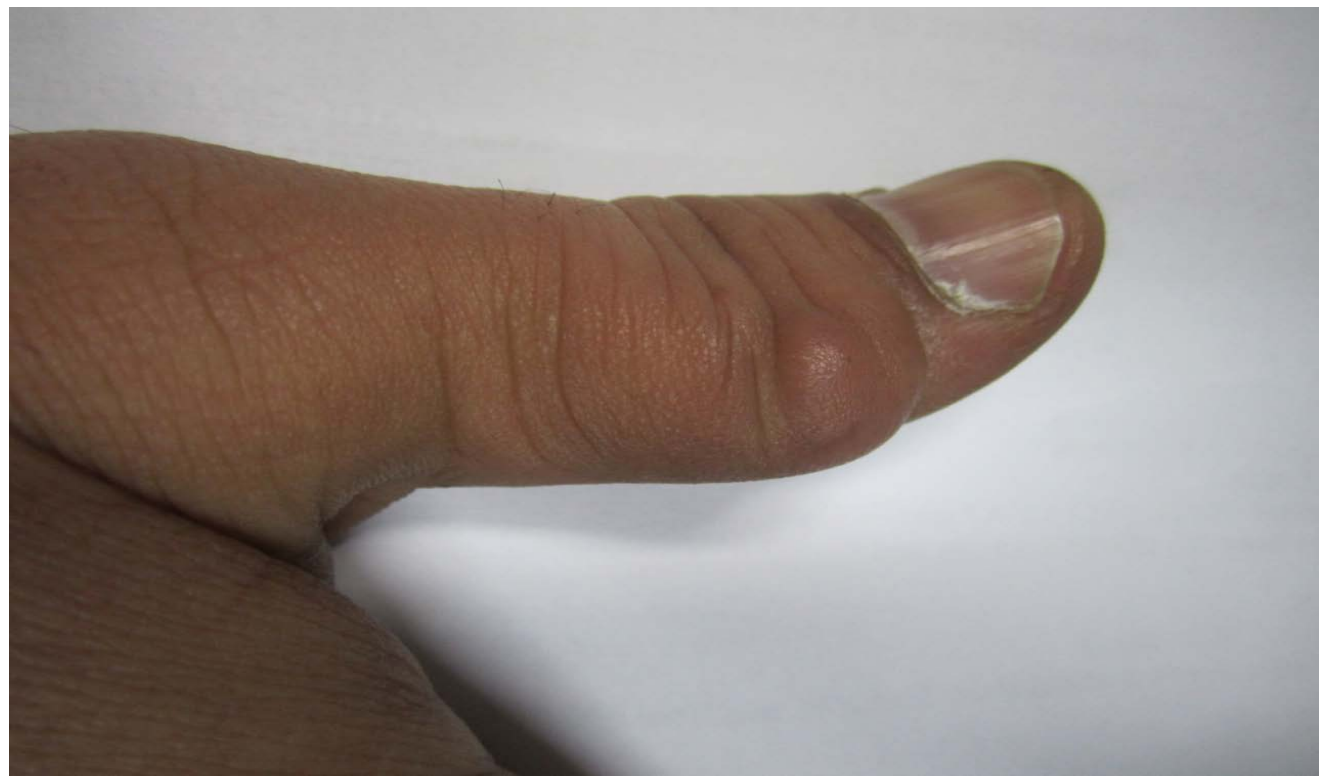

Figure 1. Mass on right thumb

Copyright (C) 2022 Meena N and Arora P. This is an Open Access article distributed under the terms of the Creative Commons AttributionNonCommercial 4.0 International License (http://creativecommons.org/licenses/by-nc/4.0/), permitting all non-commercial use, distribution, and reproduction in any medium, provided the original work is properly cited. 
Giant cell tumour of the tendon sheath (GCTTS) is a slowly growing, usually painless benign lesion of soft tissues $^{[1]}$. It is the second most common tumour of the hand after ganglion cysts. It affects individuals between the age of 30 and 50 years old and is more common in females ${ }^{[1]}$. GCTTS presents as a firm, nodular mass occurring more commonly on the volar aspect of fingers and hands ${ }^{[2]}$. The various etiological factors include trauma, neoplastic, inflammatory and metabolic disease, but it is best considered idiopathic ${ }^{[2]}$. Histologically, GCTTS is composed of multinucleated giant cells, histiocytes polyhedral, fibrotic material and hemosiderin deposits ${ }^{[1]}$. There is no report of GCTTS becoming malignant. Rate of recurrence is reported up to $45 \%$ of cases. Excision is the treatment of choice ${ }^{[1]}$.

Byers et al. classified GCTTS into two types: localized nodular (common in hand) and diffuse (common in joints) [3]. Al-Qattan proposed a new classification for GCTTS: Type-I as single tumour, which is round or multi-lobulated, and Type-II where there are two or more distinct tumours which are not joined ${ }^{[4]}$. Ultrasonography can detect whether the tumour is solid or cystic, and to note if there are satellite lesions. It also describes the relationship of the lesion to the surrounding structures ${ }^{[5]}$. Information regarding the extent of contact with the underlying tendon and the percentage of circumferential involvement is possible with sonography ${ }^{[5]}$. GCTTS appears as a solid homogeneous hypoechoic mass on ultrasonography ${ }^{[6]}$.

In GCTTS, FNAC shows a polymorphic population composed of mononuclear histiocyte-like cells, hemosiderin-laden macrophages, foamy macrophages and a few multinucleated giant cells ${ }^{[7,8]}$. FNAC can be used as a diagnostic tool for an early and accurate detection of GCTTS as the cytological features, and clinico-radiological correlation are sufficiently diagnostic ${ }^{[7,8]}$. Thus, FNAC helps in preoperative planning to prevent recurrence $^{[8]}$. Differential diagnoses of GCTTS include ganglion, lipoma, foreign body granuloma, tophaceous gout, haemangioma, glomus tumour, enchondroma, osteoid osteoma, osteoblastoma, schwannoma, and circumscribed fibromatosis ${ }^{[6]}$. Due to its location in the extremities, GCTTS also needs to be differentiated from epithelioid sarcoma, synovial sarcoma, clear-cell sarcoma, and rhabdomyosarcoma ${ }^{[7]}$. Osteoclast-type giant cells are normally absent in each of these four neoplasms, but they are frequently present in GCTTS ${ }^{[7]}$. We report this case to highlight the role of FNAC in diagnosing GCTTS.

\section{Conflict of interest}

The authors declare no potential conflict of interest with respect to the research, authorship and/or publication of this article.

\section{References}

1. Di Grazia S, Succi G, Fraggetta F, Perrotta RE. Giant cell tumor of tendon sheath: Study of 64 cases and review of literature. G Chir 2013; 34(5-6): 149-152. doi: 10.11138/gchi $\mathrm{r} / 2013.34 .5 .149$.

2. Monaghan H, Salter DM, Al-Nafussi A. Giant cell tumour of the tendon sheath (localised nodular tenosynovitis): Clinicopathological features of 71 cases. J Clin Pathol 2001; 54(5): 404-407. doi: 10.1136/jcp.54.5.404.

3. Byers PD, Cotton RE, Deacon OW, Lowy M, Newman PH, et al. The diagnosis and treatment of pigmented villonodular synovitis. J Bone Joint Surg Br 1968, 50(2): 290-305.

4. Al-Qattan MM. Giant cell tumors of tendon sheath: Classification and recurrence rate. J Hand Surg 2001; 26(1): 72-75. doi: 10.1054/jhsb.2000.0522.

5. Middleton WD, Patel V, Teefey SA, Boyer MI. Giant cell tumors of the tendon sheath: An analysis of sonographic findings. AJR Am J Roentgenol 2004; 183(2): 337-339. doi: 10.2214/ajr.183.2.1830337.

6. Darwish FM, Haddad WH. Giant cell tumour of tendon sheath: Experience with 52 cases. Singapore Med J 2008; 49(11): 879-882.

7. Gupta K, Dey P, Goldsmith R, Vasishta RK. Comparison of cytologic features of giant-cell tumor and giant-cell tumor of tendon sheath. Diagn Cytopathol 2004; 30(1): 14-18. doi: 10.1002/dc.10411.

8. Iyer KV, Kapila K, Verma K. Fine-needle aspiration cytology of giant cell tumor of the tendon sheath. Diagn Cytopathol 2003; 29(2): 105-110. doi: 10.1002/dc.10319. 